\title{
Prospects for an upper Givetian substage
}

\section{Z. Sarah Aboussalam' \& R. Thomas Becker ${ }^{1}$}

With 3 figures, 3 plates, and 2 tables

\begin{abstract}
New ammonoid and conodont data from Germany, the Montagne Noire (France) and southeastern Morocco document a complex sequence of sedimentary events and faunal changes within an extended Givetian (late Middle Devonian) Taghanic Event Interval or Taghanic Biocrisis. Direct association of supposed typical middle Givetian ammonoids, trilobites and corals with upper Givetian marker taxa such as pharciceratids have been found, for example, in Moroccan and French time equivalents of the New York Upper Tully Limestone. The initial and eustatic Taghanic Onlap level is not known to be characterized by the first appearance of any widespread index conodont, goniatite or other taxon. A future upper Givetian substage, therefore, might be based either on the entry of Ozarkodina semialternans or on the first appearance of Schmidtognathis hermainni. The semialternans Zone correlates with a third sedimentary cycle within the Tully Limestone and with the spread of the first Pharciceratidae, Eobeloceratidae (Mzerrebites juvenocostatus) and Archoceratidae n. fam. (Atlantoceras). The (Lower) hermanni Zone is marked by a post-event transgression which led to a significant conodont radiation and to a further diversification of Pharciceratidae and Eobeloceratidac (Mz. erraticus).
\end{abstract}

Key words: Middle Devonian, ammonoids, Archoceratidae, conodonts, trilobites, chronostratigraphy, global events. Morocco. France.

\section{Zusammenfassung}

Neue Ammonoideen- und Conodonten-Daten aus Deutschland, Frankreich (Montagne Noire) und aus Südost-Marokko belegen eine komplexe Abfolge sedimentärer Ereignisse und von Faunenwechseln in einem längerfristigen Taghanic-Event-Intervall bzw. einer Taghanic-Biokrise des Givetiums (oberes Mittel-Devon). Direkte Vergesellschaftungen von Ammonoideen. Trilobiten und Korallen, die früher als typische Mittel-Givetium-Formen angesehen wurden, mit Leitformen des Ober-Givetiums (z. B. Pharciceraten) konnten in Marokko und Frankreich in Zeitequivalenten des Oberen Tully-Kalkes von New York nachgewiesen werden. Der initiale und eustatisch bedingte Taghanic Onlap ist bisher nicht durch das Einsetzen eines weit verbreiteten Index-Conodonten, -Goniatiten oder eines Vertreters anderer Fossilgruppen gekennzeichnet. Eine künftige OberGivel-Unterstufe sollte daher entweder durch das Einsetzen von Ozarkodina semialternans oder durch das erste Auftreten von Schmidtognathus hermanni definiert werden. Die semialternans-Zone korreliert mit einem dritten Sedimentations-Zyklus im Tully-Kalk und mit der Ausbreitung erster Pharciceratidae, Eobeloceratidae (Mzerrebites juvenocostatus) und Archoceratidae n. fam. (Atlantoceras). Die (Untere) hermanni-Zone ist durch eine Post-Event-Transgression gekennzeichnet, welche eine wichtige Conodonten-Radiation und eine weitere Diversifizierung der Pharciceratidae und Eobeloceratidae (Mz. erraticus.s) ermöglichte.

Schlüsselwörter: Mittel-Devon. Ammonoidea, Archoceratidae, Conodonta, Trilobita, Chronostratigraphie, Globale Events, Marokko, Frankreich.

\section{Introduction}

In the classical subdivision of the German Upper Devonian by Wedekind (1913), the Pharciceras lunulicosta Zone or do I $\alpha$ (originally to I $\alpha$ ) was taken as the base of the Upper Devonian. House (1982) correlated this with the Pharciceras-bearing (House 1962) Tully Limestone of
New York and with the base of the Assise de Fromelennes, which mostly was taken as the base of the Upper Devonian in Belgium. This interpretation was adopted by subsequent authors (e.g., Johnson et al. 1985). When the revised Middle/Upper Devonian boundary was placed at the much younger base of the Ancyrodella rotundiloba Zone (Klapper et al. 1987, =

\footnotetext{
1 Muscum für Naturkunde. Invalidenstr. 43, D-10115 Berlin, Germany. E-mail: sarah.aboussalam@rz.hu-berlin.de Received May 2001, accepted July 2001
} 
base of MN Zone 1 sensu Klapper 1989). almost all pharciceratid faunal levels or most of the Pharciceras Stufe (House 1985) fell into the late Givetian. This interval was of considerable duration (more than 2 ma following House 1995) and spans as man? as 5 goniatite zones (House \& Becker 1999) and $6 \frac{1}{2}$ zones of the traditional conodont zonil scheme: the upper part of the Middle varcus Zone, the Upper varcus Zone, the Lower hermanni Zone. the Upper hermanni Zone, the Lover disparilis Zone. the Upper disparilis Zone, and the norrisi Zone (lowest part of the Lower falsiovalis Zone $=$ former Lowermost asymmet icus Zone).

With respect to the classical boundary and to significant global faunal differences (e.g., the boundary between the Maenioceras = MD II and Pharcicer.zs Stufe = MD III) caused by the global Tagharic Event (House 1985). it seems logical to plare the base of an upper Givetian substage at the position of the old Upper Devonian base. Rerent detailed work on the Taghanic Event in North America (Brett et al. 1999). in Germany, the Montagne Noire and Morocco (Aboussalam 2000), including a lot of new conodont and gor iatite data, however, showed that the sequence of faunal and sedimentary changes is rather cornplex (Fig. 1). It also should be noted that the term upper Givetian has been used in the past by various authors working on neritic successions of the western and eastern Rhenish Massive in rather different ways and including older levels (e.g.. in the sense of the "Iserlohnium", see Struve 1992).

In all inves igated areas it is evident that there is not just one level of global extinction. faunal change and of eustatic rise associated with the "Taghanic Orlap" (Johnson 1970), but a staged sequence of events (Fig. 1). For example. the New York Tully Limestone cannot only be di- vided into lower and upper members (Heckel 1973) but Brett et al. (1999) recognized three sedimentary sequences, with a second sequence boundary and start of a third division beneath the Bellona-West Brook Beds, within Heckel's upper member. Equivalents of $1^{\text {st }} / 2^{\text {nd }}$ (lower member to lower half of upper member) and of the $3^{\text {rd }}$ Tully sequence (Bellona-West Brook, Moravia and Fillmore Glen Beds) can be recognized in many European and Moroccan sections. Recognition of three Tully subdivisions with separation of a West Brook Member goes back to Cooper \& Williams (1935) and Cooper (1967). The whole period from the sharp regression at the top of the Hamilton Group (from the subTully sequence boundary of Brett \& Baird 1996) to the base of the Geneseo Shale, the Tully Limestone time equivalents (compare House 1983. 1989), is taken as extended Taghanic Event Interval or Taghanic Biocrisis (Fig. 1).

Abbreviations: Po. $=$ Polygnathus, Schm. $=$ Schmidtog nathus. $O-.=$ Ozarkodina, $I .=$ Icriodus, $P h .=$ Pharciceras, Maenio. = Maenioceras. All illustrated material is deposited in the Museum für Naturkunde, Berlin.

\section{Investigated Sections with new Ammonoid and Conodont Data}

Late Givetian sections have been described from around the world but none has been documented so far in sufficient detail to serve as a reference section for the middle/upper Givetian transition. It is recommended to search for a section in pelagic facies with good representation of several faunal groups, including diverse benthic organisms and, if possible, also miospores. Among the numerous European-North African localities studied by us in the last years in detail, none gave a perfect sedimentary and faunal sequence.

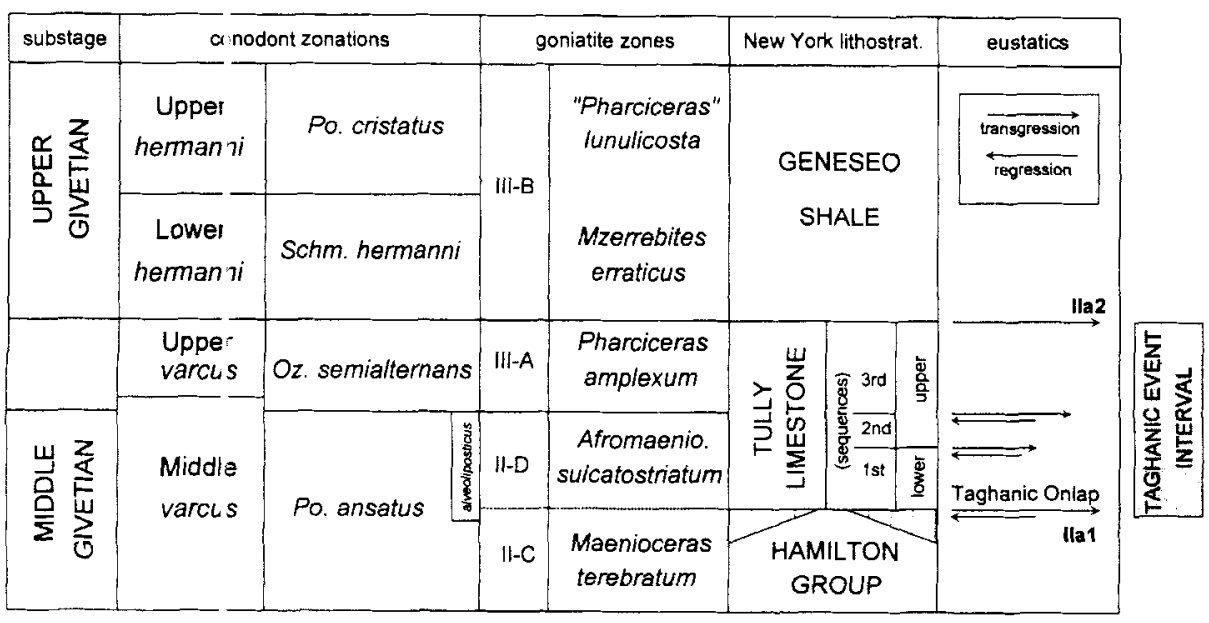

Fig. 1. Middle to upper Givetian chrono-, bio-, litho- and sequence stratigraphy. 


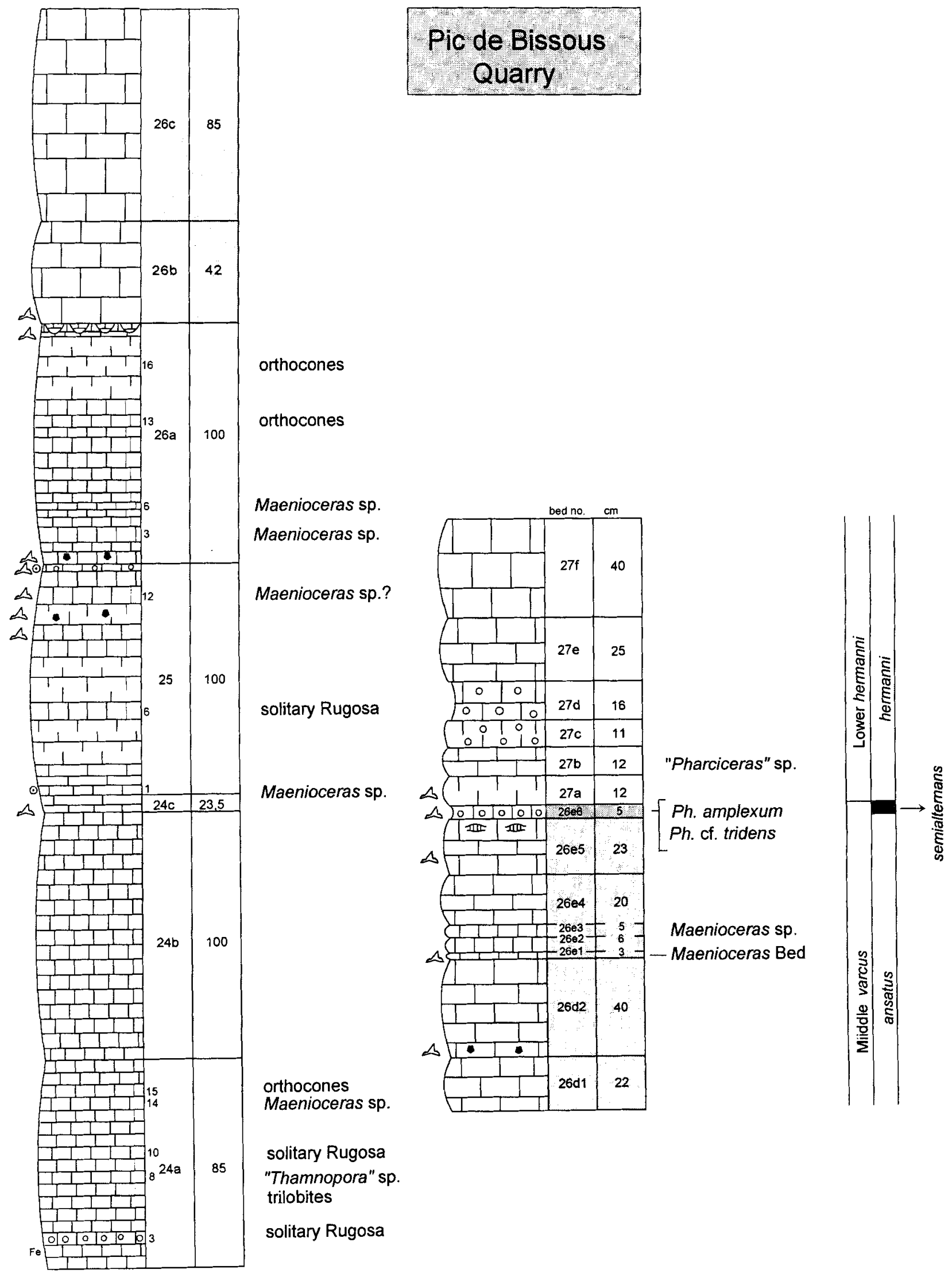

Fig. 2. Sedimentary and faunal succession in the middle to upper Givetian at Pic de Bissous Quarry (Marbriére Nord) showing the position of conodont samplex and of macrofaunal levels. The extended Taghanic Event Interval is shaded. 
German sectic ns in pelagic limestone facies (e.g.. Syring and Blauer Bruch, Kellerwald. see Ebert 1993) are all very poor in macrofauna. Sealevel changes assoc ated with the Taghanic Onlap and later regressive events often cause unconformities, for exam le along the Mont Peyroux and in the Cabrières area of the Montagne Noire (Feist \& Klapper 1985), or on the central Tafilalt Platform of southeastern Morocco (Jebel Amelane. Jebel Mech Irdane. Seheb-el-Rhassal. Hamar Laghdad). More basinal and less condensed sections of southern Morocco are often incredibly rich in well $\mathrm{freserved}$ goniatites (Hassi Nebech. Tata region. Bensaid 1974) but the conodont record is very poor. even in intercalated limestone beds. Only 1wo well-known sections currently have good goniatites and a sufficient record of important marker conodonts: Pic de Bissous Quarry of the Montagne Noire, and Bou Tchrafine in the Tafilalt.

\section{Pic de Bissous Quarry (Marbrière Nord)}

The marble quarry on the northern slope of Pic de Bissous. ca. $3 \mathrm{~km} \mathrm{~N}$ of Cabrières (Fig. 2; precise location see Feist \& Klapper (1985: textfig. 3). or Becker (1993: fig. 15), has been long known as an important Middle Devonian fossil locality. The succession is completely overturned but the succession is not disturbed by tectonics. Hematite-rich, red Givetian hemipelagic limestones are strongly cyclic (House 1995) and contain goniatites, orthocones, crinoid remains, trilo-

\begin{tabular}{|c|c|c|c|c|c|c|c|c|c|c|c|c|}
\hline \multicolumn{13}{|c|}{ Pic de Bissous Quarry } \\
\hline conodont zones & & & & & ansatu & $Z$ one & & & & & $\operatorname{sen} 2$ & her.Z. \\
\hline bed and sample no. & $24 \mathrm{cl}$ & $25(1)$ & $25(10)$ & $25(11)$ & $26 \mathrm{a}(1)$ & $26 \mathrm{a}(18,19)$ & $26 \mathrm{~b}(1)$ & $26 \mathrm{~d} 2$ & $26 \mathrm{e} 1$ & $26 \mathrm{e} 5$ & $26 e .6$ & $27 a$ \\
\hline Po, varcus & 2 & $*$ & 1 & 3 & 4 & 7 & 1 & 3 & * & 7 & 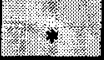 & 3 \\
\hline Po. ling. klappiri & 1 & * & 2 & 1 & * & $*$ & * & 3 & 1 & 3 & 1 & \\
\hline Po. ling. linguiformis & 13 & * & 25 & 32 & 33 & 13 & 8 & 25 & 3 & 23 & 3 & \\
\hline Po. hemiansatzs & & w & & & & & & & & & 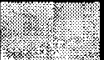 & \\
\hline Po. ansatus & * & w & $*$ & * & * & * & * & * & $\mathrm{w}$ & & $3^{3}=x^{2}$ & \\
\hline Po. ling. mucrunatus & & & 1 & * & 1 & $*$ & * & * & * & 2 & 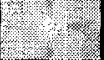 & \\
\hline Po. ling wedd gei & & & & 1 & 3 & * & 1 & * & * & 1 & 4. & \\
\hline Po.timorensis & & & & & 2 & 1 & * & 1 & 1 & 4 & 4 & W \\
\hline 1. difficilis & & & & & 2 & & & & & & (2) & \\
\hline Lateri. latericrescens & & & & & 1 & & & & & & 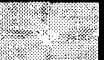 & \\
\hline Oz. semialternans & & & & & W? & & & & & & 2 & 1 \\
\hline Tortodus spp. & & & & & & & 1 & $*$ & * & $*$ & $*$ & 2 \\
\hline 1. obliquimarginatus & & & & & & & & & W & cf. & *. & cf. \\
\hline Po.xylus & & & & & & & & & & 3 & * & 5 \\
\hline Po. ovatinodo.us & & & & & & & & & & 1 & 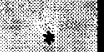 & 23 \\
\hline Schm. latufossutus & & & & & & & & & & & 2 & 4 \\
\hline Schm, hermaini & & & & & & & & & & & 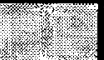 & 2 \\
\hline Schm. witteki, dti & & & & & & & & & & & 2 & 2 \\
\hline Po. limitaris & & & & & & & & & & & 2.2 & 4 \\
\hline
\end{tabular}

Table 1. Conocont succession at Pic de Bissous Quarry. $W=$ records of Walliser (1990). Shaded areas = extended Taghanic Event Interval. 
bites, solitary rugose corals, rare tabulate corals, inarticulate brachiopods, bivalves, ostracods, dacryoconarids, agglutinating foraminiferans and moderately rich conodont assemblages. The dominating lithologies are internally layered and often styliolinid-rich bioclastic wackestones to packstones with ostracods, trilobites and crinoidal debris (Pl. 3: 8). Goniatites are enriched in specific thin units such as Beds 26e $\mathrm{e}_{1}$ (Maenioceras $\mathrm{Bed}=$ youngest subunit of Bed $\mathrm{R}$ in House 1995) and 26e 6 (Pl. 3: 7) which may reflect levels of minor deepening and of increased trophic level. Episodic coarse crinoidal debris limestones (e.g., Beds 25(11), 26a(1), 26d2(1), see $\mathrm{Pl}$. 3: 5) were deposited during storms or short-termed shallowing phases.

Apart from some preliminary data of Walliser (1990), whose bed numbering has been mostly adopted and extended, the conodonts of the quarry have largely remained unstudied. Faunas from the upper part of Middle varcus Zone to basalmost Frasnian, however, were described from a nearby section at the western slope of Pic de Bissous (Feist \& Klapper 1985: section VS-W; goniatites in House et al. 1985). Our conodont succession (Table 1) starts with Bed 24c which falls in the ansatus Zone (ca. middle part of Middle varcus Zone). Po. ansatus was found in Bed 25(1) but Walliser (1990) noted it at a much older level higher up in the quarry (youngest part of Bed 17). Latericriodus (Pl. 2: 18; compare records in Feist \& Klapper 1985) forms a minor element of Montagne Noire ansatus (Middle varcus) Zone faunas. A significant unconformity with erosional contact at the boundary between Beds $26 \mathrm{a}$ and $26 \mathrm{~b}$ has previously been unnoticed. In sequence stratigraphic terms, it seems likely that this sedimentary break correlates with the regression-transgression couplet of the initial Taghanic Event.

The mass occurrence of Maenioceras terebratum Group (e.g., MB.C.3607) in Bed 26 $\mathrm{e}_{1}$ (= Bed 26c in Walliser 1990) at the floor of the quarry still falls in the ansatus (Middle varcus) Zone. It is tempting to correlate this unusual unit with the 2nd Tully transgression at the base of its upper member. There is evidence of an additional sedimentary break and erosional events within haematite-rich styliolinid wackestones of Bed $26 \mathrm{e}_{5}$ (PI. 3; 6). The dark red and nodular Bed $26 \mathrm{e}_{6}$ is only exposed in the eastern quarry corner and yielded for the first time in Europe Pharciceras amplexum (Pl. 1: 1-2) together with rather evolute $P h$. cf. tridens (Pl. 1: 7). As in the Moravia Bed of New York, this unit contains $O z$. semialternans (PI. 2: 9) and can be precisely correlated with the 3rd Tully sequence. The erosional unconformity of Bed $26 \mathrm{e}_{5}$ indicates a sequence boundary just below, still in the topmost ansatus Zone (Middle varcus Zone). The semialternans Zone, unfortunately, is very condensed since the following Bed 27a gave a typical and diverse hermanni Zone fauna with Po. limitaris (P1. 2: 20), Schm. latifossatus and others. Pharciceratids from Bed $27 \mathrm{~b}$ are too poorly preserved for identification.

The described sequence suggests that more efforts should be undertaken to investigate the Pic de Bissous rugose corals, trilobites and ostracods.

\section{Bou Tchrafine}

The Bou Tchrafine section $S$ of Erfoud in the central Tafilalt has been described by a wide range of authors. The middle to late Givetian conodont succession was investigated by Bultynck \& Hollard (1980), Bultynck \& Jacobs (1981), Ziegler \& Klapper (1982), Bensaid et al. (1985), Bultynck (1987) and Ebert (1993). Goniatite data were included in Bensaid et al. (1985) and Ebert (1993); a more detailed summary was provided by Becker \& House (1999). Based on this background we have specifically resampled the levels from below the Taghanic Event (upper Maenioceras Marls) to the Lower Marker Bed (Fig. 3) of the Po. cristatus Zone (= Upper hermanni Zone).

The sequence consists of yellowish-grey, nodular marls (Bed A0 = BT 30), massive and very solid, bluish-grey micrites with some goniatites, relative rich conodonts and bioturbated upper surfaces (Sellagoniatites Limestone and Lower Marker Bed), thin shale/marl interbeds, and yellowish, styliolinid-rich and somewhat argillaceous, fossiliferous, bioturbated, partly still layered micrites with goniatites, orthocones, Pterochaenia-like bivalves, brachiopods, crinoid remains, rare tabulate corals, foraminiferans (e.g.. Webbinelloidea, Pl. 2: 16), smooth ostracods, phacopids, harpids and tentaculites (Beds A4 to B4). A microfacies analyses (Pl. 3: 1-4) showed that carbonates rather uniformly consist of styliolinid wackestones to packstones with ostracods, trilobites and rare crinoid remains. Mudstone intervals (Pl. 3: 2) indicate episodic decpening, packstones (Pl. 3: 1) formed during minor shallowing phases with increased bottom turbulance and removal of fine micritic matrix. It is obvious that most beds consist of several depositional units, 


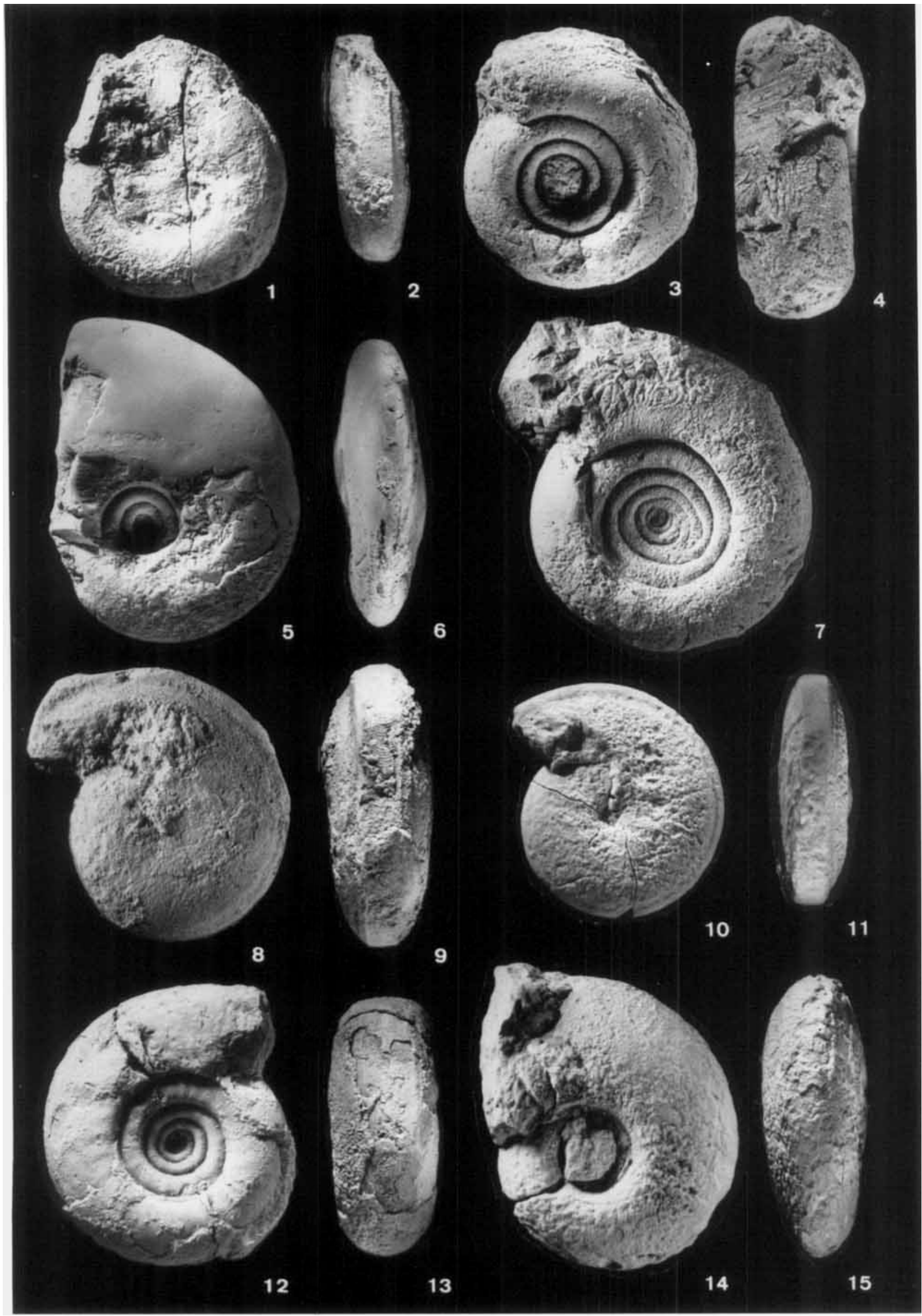


perhaps each representing one orbital cycle, and separated by inconspicuous unconformities. Bed boundaries reflect somewhat stronger signals of sedimentary cyclicity and sealevel fluctuations.

Beds A0 to A3 (BT 30-31c, Table 2) fall in the higher part of the ansatus Zone (Middle varcus Zone); Bultynck (1987) and Lotmann (1990) recorded Po. ansatus from well below the Maenioceras Marl (= Bed A0). An intermediate between Po. ansatus and $O z$. semialternans was found by Bultynck (1987) in his sample 30bis near the top of Bed A0. Po. ovatinodosus (Table 2, Pl. 2: 1) is now locally first recorded from the middle part of the Sellagoniatites Limestone (Bed A2 = BT 31b) which contains the namegiving marker goniatite. At its top (top of Bed A3) there is a distinctive erosional surface and a thin shale unit. Based on sequence stratigraphy, we correlate the overlying styliolinid-rich Bed A4 (Pl. 3: 2, = BT 32 in Bensaid et al. 1985 and Ebert 1993), which has poor macrofauna and which consists of two subunits, with the $1^{\mathrm{st}} / 2^{\text {nd }}$ sequences of the Tully Limestone. Conodonts still fall in the ansatus Zone (Middle varcus Zone) and its top is also rather irregular suggesting another discontinuity surface.

Bed B1b (= BT 33a in Ziegler \& Klapper 1982, Bensaid et al. 1985 and Ebert 1993; BT 32 in Bultynck \& Jacobs 1981, includes Bed B2 of Becker \& House 1999) is the famous unit with Pharciceras aff amplexum (which will be placed in a new species, Pl. 1: 3-4). Detailed sampling showed that poorly preserved Maenioceras are still rather abundant (MB.C.3305.1-7) and associated with the last rare Sellagoniatites (PI. 1: 5-6) and the first Epitornoceras. The presence of $O z$. semialternans was confirmed (Pl. 1:8) but conodont samples are not rich. The overlying
Beds B2-B4 (= BT 33b-d) have a typical and rather diverse fauna of the hermanni Zone. At the base of the zone (Bed B2), Schm. hermanni (Pl. 2: 4), Sch. pietzneri (Pl. 2: 2-3), Schm. wittekindti (Pl. 2: 5), Po. limitaris (Pl. 2: 14a-b), Schm. latifossatus (PI. 2: 13) and $O z$. proxima (Pl. 2: 7) enter. Bed B2 (= BT 33b, including fauna placed in Bed B3 in Becker \& House 1999), yielded Mzerrebites erraticus and a closely related, somewhat thicker form (compare specimen from Jebel Amelane, Pl. 1: 14-15) but no pharciceratids. In neighbouring sections (Seheb el Rhassal), the multilobate and evolute "Pharciceras" lunulicosta Group (Gen. nov.) enters in equivalents of Beds B3/B4.

The lower part of the Upper Marker Bed (Bed C1 = BT 34) has been dated by Bensaid et al. (1985) and Ebert (1993) as Upper hermanni Zone which is defined by the entry of Po. cristatus Hinde. As repeatedly noted (Kirchgasser 1970, Huddle 1981; compare discussion in Ziegler \& Klapper 1982), the holotype of Po. cristatus differs from Po. cristatus sensu Bischoff \& Ziegler (1957) in ornamentation (with partly fused nodes in two rows, the outer of which runs around the platform margin) and in its dorsal carina which does not reach the posterior tip of the platform. It is probably appropriate to restrict the name Po. cristatus to morphotypes resembling the holotype. In such a taxononomic concept, Po. ectypus Huddle becomes available as the correct name for Po. cristatus sensu Bischoff \& Ziegler. The cristatus lectotype lies outside the variation of an Illinois population illustrated by Orr (1964) but he (text-fig. 4C), as well as Bultynck \& Jacobs (1981, pl. VII, figs $11 a-b)$, illustrated single specimens with ectypus-type nodation and cristatus-type short med-

Plate 1. Goniatites from around the Taghanic Event Interval of Morocco and of the Montagne Noire. 1-2. Pharciceras amplexum (Hall), MB.C.3300.1, Pic de Bissous Quarry, Bed 26e6, semialternans Zone, incomplete specimen, $\times 1$; 1, lateral view. and 2, ventral view showing typical, strong ventrolateral furrows and cross-section with flat venter. 3-4. Pharciceras aff. amplexum (Hall), MB.C.3151.3, Bou Tchrafine, Bed B1b, semialternans Zone, small specimen with sutures; 3, lateral view. $\times 2.2$, and $\mathbf{4}$, ventral view, $\times 2.5$, showing the rounded cross-section at ca. $20 \mathrm{~mm}$ diameter lacking prominent furrows. 5-6. Sellagoniatites discoides (Waldschmidt), MB.C.3302.1, Bou Tchrafine, Bed B1b, semialternans Zone, $\times 1$; 5, lateral view showing rapid whorl expansion, and 6, ventral view showing typical and strong shell compression. 7. Pharciceras cf. tridens (Sandberger \& Sandberger), MB.C.3301, Pic de Bissous Quarry, Bed 26e6, semialternans Zone, relative evolute and compressed morphotype (or subspecies) lacking furrows, $\times 1.5$, lateral view. The irregular coiling of early whorls is an artefact of preparation. 8-9. Maenioceras aff. terebratum (Sandberger \& Sandberger), MB.C.3303.1, Col de Tribes South, Bed 45, semialternans Zone, $\times 1.5 ; 8$, lateral view showing strong ventrolateral furrows, and 9, ventral view, showing thicker whorls than in the terebratum lectotype of Becker \& House (1994). 10-11. Maenioceras terebratum (Sandberger \& Sandberger), MB.C.3306, Jebel Amelane, Section 1 (see Becker \& House 1994), loose specimen from Maenioceras Marls (terebratum Zone), typical strongly compressed morphotype, $\times 1.5 ; \mathbf{1 0}$, lateral view, and 11, ventral view showing thinner whorls than in Maenio. aff. terebratum (see Fig. 9). 12-13. Pharciceras aff. amplexum (Hall), MB.C.3304.1, Col de Tribes South, Bed 45, semialternans Zone, $\times 1.5 ; 12$, lateral view showing biconvex growth lines, and 13, ventral view showing broad whorl profile and weak ventrolateral furrows at $30 \mathrm{~mm}$ diameter. 14-15. Mzerrebites aff. erraticus (Petter), MB.C.3166, Jebel Amelane, Section 1, loose specimen, probably from the erraticus Zone, $\times 1.5 ; \mathbf{1 4}$, lateral view, and $\mathbf{1 5}$, ventral view showing wider whorls than in typical Mz. erraticus. 


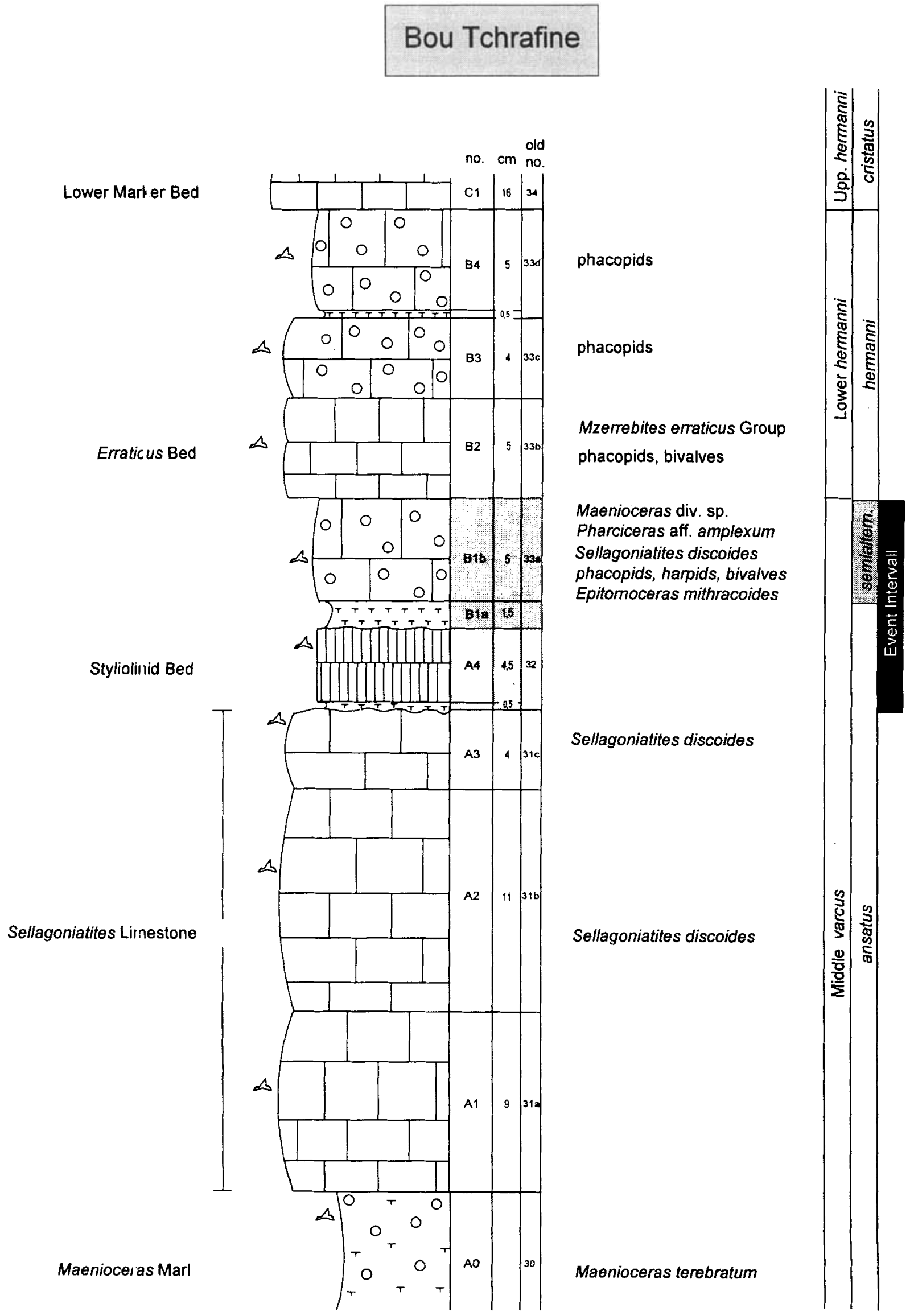

Fig. 3. Sedimentaly and faunal succession in the middle to upper Givetian at Bou Tchrafine (section of Bultynck \& Hollard 1980 and Bultyncl. 1987) showing the position of new conodont samples and the macrofaunal record. Shaded area $=$ Taghanic Event Interval. 


\begin{tabular}{|c|c|c|c|c|c|c|c|c|c|c|}
\hline \multicolumn{11}{|c|}{ Bou Tchrafine } \\
\hline conodont zones & \multicolumn{4}{|c|}{ ansatus $Z$ one } & \multirow{2}{*}{\multicolumn{2}{|c|}{ sent 2}} & \multicolumn{3}{|c|}{ hermanni Zone } & cr. $\mathbf{Z}$. \\
\hline bed and sample no. & A0 & A1 & $\mathrm{A} 2$ & $\mathrm{~A} 3$ & & & $\mathrm{~B} 2$ & B3 & B4 & $\mathrm{Cl}$ \\
\hline Po.varcus & 1 & 2 & 30 & 39 & 4 & B. & 13 & 9 & * & $\mathrm{B}$ \\
\hline Po.rhenanus & $\mathrm{B}$ & $*$ & B? & & & 2 & & & & \\
\hline Po. ling. linguiformis & 20 & 21 & 224 & 121 & 34 & 4. & & & & \\
\hline Po. ling. mucronatus & 1 & 3 & 7 & 4 & 2 & 20 & & & & \\
\hline Po. ling. weddigei & 1 & 1 & 24 & 8 & 3 & 10 & & & & \\
\hline Po. timorensis & $\mathrm{B}$ & $*$ & 23 & 10 & 1 & E & 3 & & & \\
\hline Tort. beckmanni & $\mathrm{B}$ & $*$ & $*$ & $*$ & $*$ & B & & & & \\
\hline Po. ansatus & $*$ & $*$ & 27 & 7 & $*$ & * & 8 & & & \\
\hline Po.xylus & $*$ & $*$ & 20 & 9 & $E$ & - & 3 & 6 & 4 & \\
\hline Po. ling. klapperi & $*$ & * & 7 & 6 & 1 & 2. & & & & \\
\hline 1. difficilis & $*$ & $*$ & 2 & $*$ & $*$ & * & 8 & & & \\
\hline Po. ovatinodosus & & & 12 & 1 & 2 & E & 8 & 8 & $*$ & $\mathrm{~B}$ \\
\hline Tortodus spp. & & & & 4 & 1 & 1 & & & & \\
\hline Oz. semialternans & & & & & & 1 & 2 & $*$ & 1 & $\mathrm{~B}$ \\
\hline Oz. proxima & & & & & & 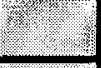 & 3 & & & \\
\hline Oz. sannemanni & & & & & & 2 & 1 & & & \\
\hline Schm. latifossatus & & & & & & 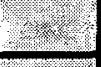 & & 1 & $*$ & $\mathrm{~B}$ \\
\hline Schm. hermanni & & & & & & & 27 & 11 & 2 & $\mathrm{~B}$ \\
\hline Schm. wittekindti & & & & & & & 4 & 6 & 1 & B \\
\hline Schm. pietzneri & & & & & & 8 & 1 & 1 & $*$ & $\mathrm{~B}$ \\
\hline Po. limitaris & & & & & & & 1 & 4 & 2 & \\
\hline Elsonella rhenana & & & & & & 2 & & 1 & & \\
\hline Po. cristatus & & & & & & & & & & B \\
\hline
\end{tabular}

Table 2. Middle to late Givetian conodont succession at Bou Tchrafine, based on new samples and records of Bultynck (1987: B) and Ebert (1993: E). Shaded area = Taghanic Event Interval.

ian carina. Both taxa seem to have come from the same stratigraphical level (North Evans Limestone) of New York.

Possible levels for the base of an upper Givetian substage

The discovery of intermediate pelagic faunas with mixtures of previously supposed typical middle and upper Givetian taxa together with other data on ammonoid and conodont occurences allow a critical evaluation of three levels which should be considered for a formal definition of an upper Givetian substage: the initial Taghanic Onlap, levels around the base of the traditional Upper varcus Zone, and the base of the hermanni Zone. Any decision should incorporate additional data based on miospores, vertebrates and neritic faunas but these have not 

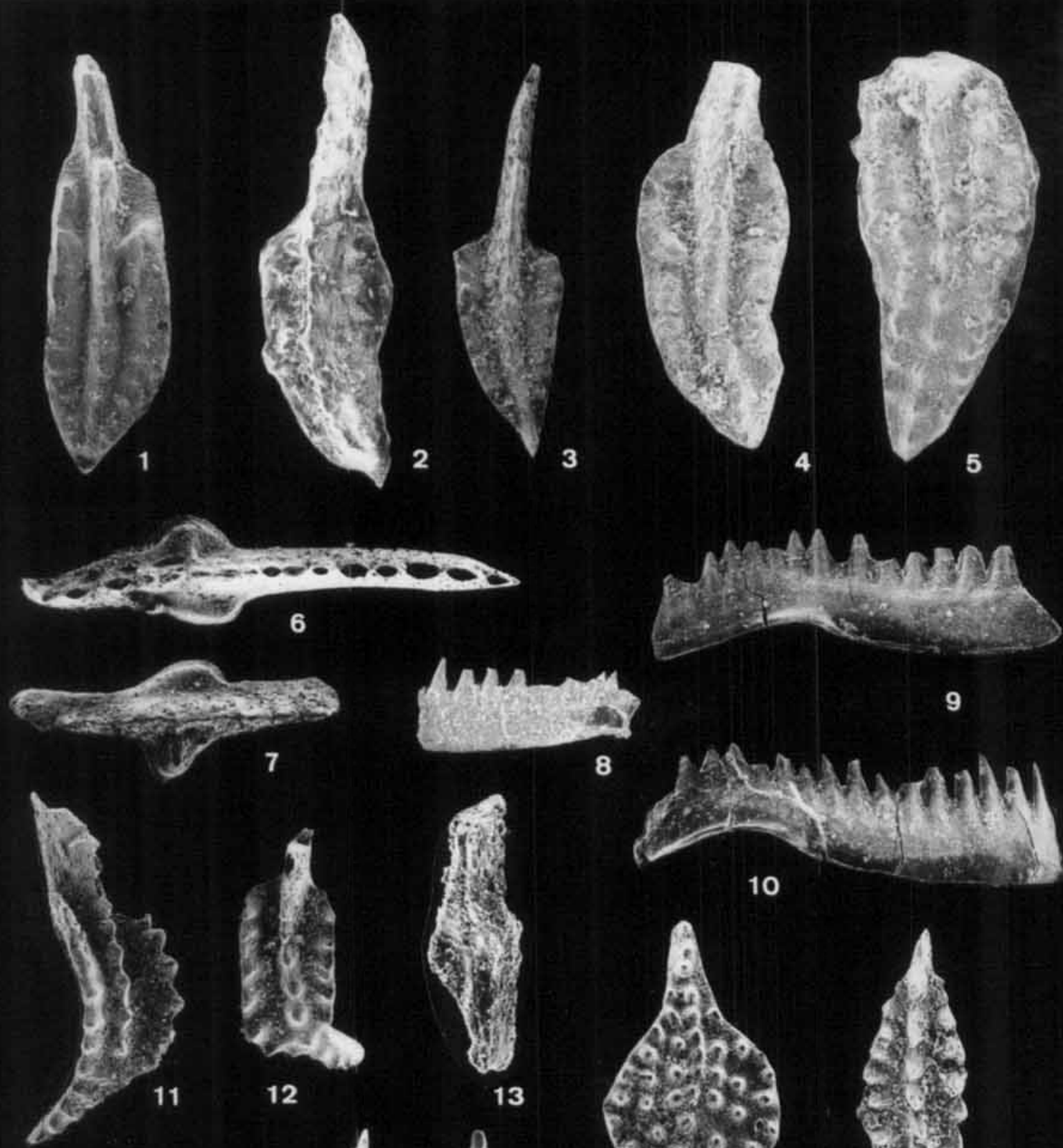

9

8
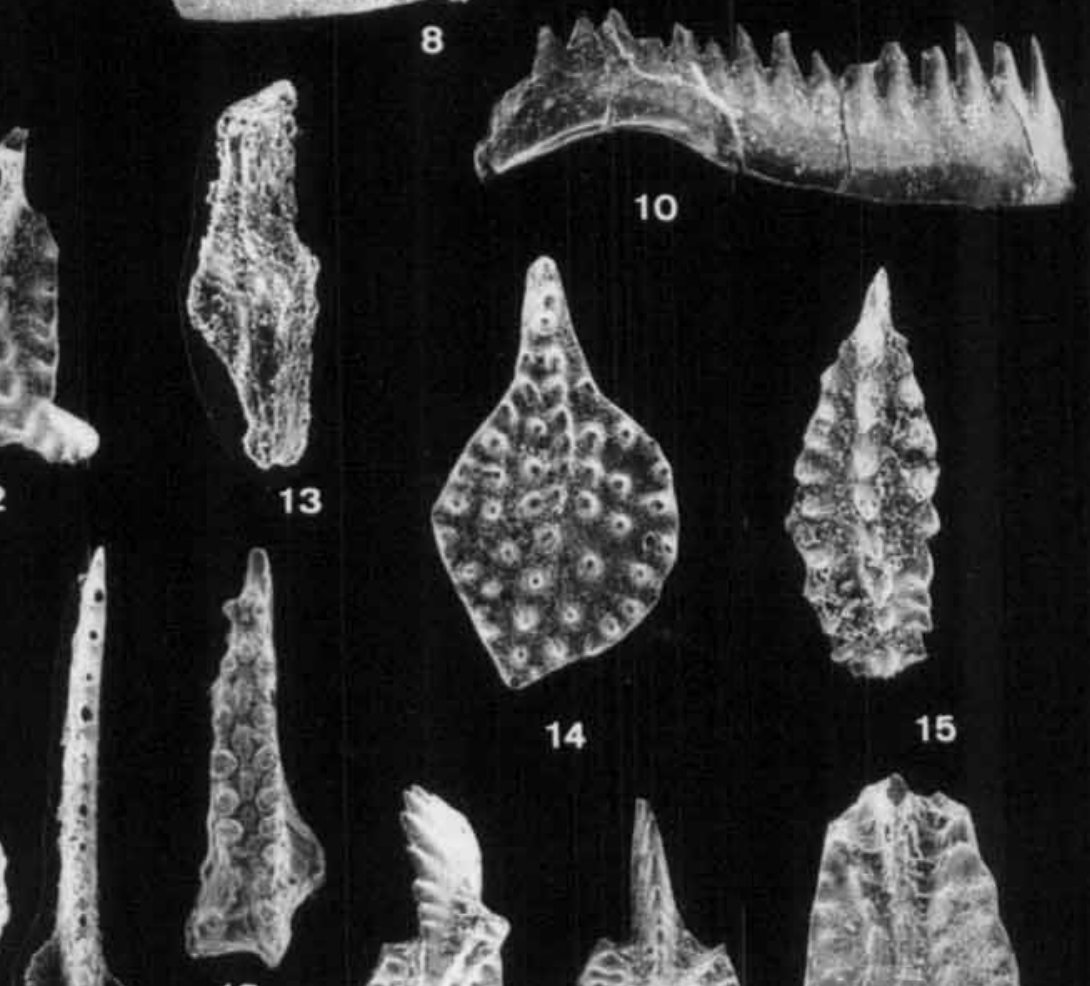

14

15
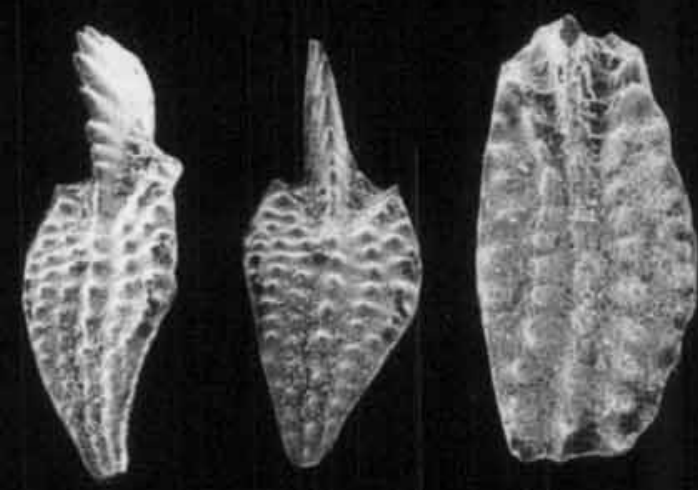

19 a

$19 b$

20 
yet been used for detailed international correlation. It is worth mentioning that stringocephalid brachiopods range above all the levels under discussion.

\section{Base of Taghanic Onlap}

The initial transgressive pulse at the base of the mostly unconformable Lower Tully Limestone (Fig. 1) has been correlated with the Belgian transgression of the Fromelennes Formation over the Calcaire de Givet and with many other regional deepening events of North America and Eurasia (House 1975, 1983, Johnson et al. 1989, Ebert 1993, Day 1996a). New data by Bultynck et al. (2001), however, indicate that the Fromelennes Formation began as early as in the upper part of the Lower varcus Zone (timorensis Zone). This is in conflict with a record of Stringodiscus? birenheidei in the basal Fromelennes Formation (Struve 1992), a species which otherwise is only known from Flinz limestones (Schleddenhof Beds) above the thick middle Givetian reef limestones (Massenkalk Formation) of the Iserlohn area in the northern Rhenish Massive.

Johnson et al. $(1985,1989)$ recognized the Taghanic Onlap as the start of their international Depophase IIa. The initial pre-Tully regression/ Tully transgression couplet is assumed to have coincided with significant extinctions in ammonoids (House 1985, 1989, Becker \& House 2000) and trilobites (Cheiruridae, Lichidae, Calmoniidae, Eremiproetinae, Cyphaspidinae, most Proetinae, many Dechenellinae, Otarioninae and $\mathrm{Au}-$ lacopleurinae; Feist 1991, Chlupac et al. 2000). Many other faunal groups, such as rugose and tabulate corals (e.g., Oliver \& Pedder 1994), brachiopods (Cooper \& Williams 1935, Dutro 1981), stromatoporoids (e.g, Mistiaen in Brice et al. 1976) and ostracods (e.g., Lethiers in Brice et al. 1976) were affected by the Taghanic Event but the precise timing of their extinctions is either still unknown, was stepwise (Dutro 1981, Day 1996b), or much influenced by regional factors. A first range compilation of many faunal groups by Ebert (1993), unfortunately, needs considerable revision and elaboration. Despite the fact, that the Taghanic Onlap seems to be recognizable on a global scale, serious reasons speak against its use as substage boundary level:

a. The initial Taghanic Onlap falls within the Middle varcus Zone (ansatus Zone of Bultynck 1987) and currently there is no index conodont, ammonoid or any other international faunal marker available that allows an easy recognition of the onlap level. In many of our sections the identification of the onlap level had to be based on sequence stratigraphy. In North American interior basins, Day (1996a, 1996b) underlined the immigration of

Plate 2. Conodonts and foraminiferans from around the Taghanic Event Interval of Morocco and of the Montagne Noire. 1. Polygnathus ovatinodosus Ziegler, Klapper \& Johnson, Bou Tchrafine, Bed A2, middle Sellagoniatites Limestone, upper part of ansatus Zone, incomplete and relatively weakly ornamented specimen, $\times 55.2$. Schmidtognathus pietzneri Ziegler. Bou Tchrafine, Bed B2, erraticus Bed, basal (Lower) hermanni Zone, large specimen, $\times 50$. 3. Schmidtognathus pietzneri Ziegler, Bou Tchrafine, Bed B2, erraticus Bed, basal (Lower) hermanni Zone, small specimen, $\times$ 85. 4. Schmidtognathus hermanni Ziegler, Bou Tchrafine, Bed B2, erraticus Bed, basal (Lower) hermanni Zone, incomplete specimen, upper view, $\times 85.5$. Schmidtognathus wittekindti Ziegler, Bou Tchrafine, Bed B2, erraticus Bed, basal (Lower) hermanni Zone, incomplete specimen, $\times$ 85. 6. Ozarkodina sannemanni Bischoff \& Ziegler, Bou Tchrafine, Bed B2, erraticus Bed, basal (Lower) hermanni Zone, upper view, $\times$ 55. 7. Ozarkodina proxima (Pollock) Bou Tchrafine, Bed B2, erraticus Bed, basal (Lower) hermanni Zone, upper view, $\times 55.8$. Ozarkodina semialternans Wirth, Bou Tchrafine, Bed B1b, Pharciceras aff. amplexum Bed, semialternans Zone, fragmentary specimen, lateral view, $\times 55.9$. Ozarkodina semialternans Wirth, Pic de Bissous Quarry, Bed $26 \mathrm{e} 6$. Pharciceras amplexum Bed, semialternans Zone, lateral view, $\times 85.10$ Ozarkodina semialternans Wirth, Col de Tribes South, Bed 46, Pharciceras aff. amplexum Beds, semialternans Zone, lateral view, $\times 85$. 11. Polygnathus linguiformis mucronatus Wittekindt, Bou Tchrafine, Bed A3, top Sellagoniatites Limestone, upper part of ansatus Zone, slightly oblique view, $\times 55.12$. Polygnathus linguiformis mucronatus Wittekindt, Bou Tchrafine, Bed A3, top Sellagoniatites Limestone, upper part of ansatus Zone, upper view of a second specimen, $\times 55.13$. Schmidtognathus latifossatus (Wirth), Bou Tchrafine, Bed B2, erraticus Bed, basal (Lower) hermanni Zone, lower view of incomplete specimen showing the Schmidtognathus-type large basal cavity, $\times 55$. 14. Polygnathus alveoliposticus Orr \& Klapper, Seheb el Rhassal, top Bed D2, top Sellagoniatites Limestone, upper part of ansatus Zone, wide morphotype, $\times 55$. 15. Polygnathus alveolipoticus Orr \& Klapper, Martenberg (Rhenish Massive), section at northern comer, top Bed $-3 \mathrm{~B}$, semialternans Zone, narrow morphotype, $\times 55$. 16. Webbinelloidea similis Stewart \& Lampe, unusually complex morphotype $(=$ Webb. disparicella Summerson, see similis Subgroup IIIA in Conkin \& Conkin 1970), Bou Tchrafine, Bed B1b, Pharciceras aff. amplexum Bed, semialternans Zone, $\times 30.17$. Polygnathus timorensis Klapper, Bou Tchrafine, Bed A3, top Sellagoniatites Limestone, upper part of ansatus Zone, specimen with asymmetric platform, $\times 85.18$. Latericriodus latericrescens (Branson \& Mehl), Pic de Bissous Quarry, Bed 26a (1), ansatus Zone, incomplete specimen, $\times 85$. 19. Polygnathus limitaris Ziegler, Klapper \& Johnson, Bou Tchrafine, Bed B2, erraticus Bed, basal (Lower) hermanni Zone, slightly oblique (a) and upper view (b) $\times 50$. 20. Polygnathus limitaris Ziegler, Klapper \& Johnson, Pic de Bissous Quarry. Bed $27 \mathrm{a}$, basal (Lower) hermanni Zone, incomplete specimen, $\times 85$. 

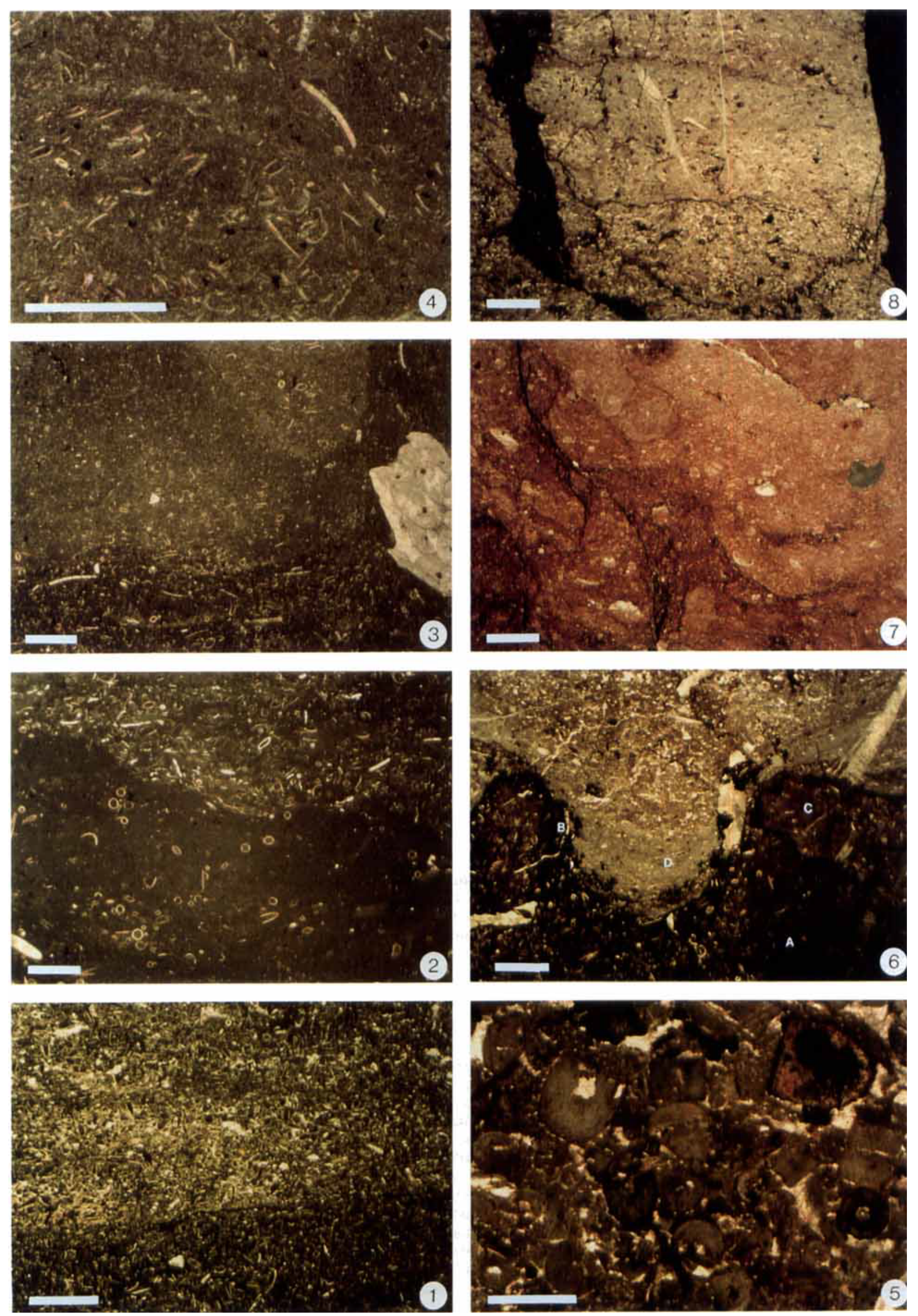
longer-ranging Old World Realm and Eastern American brachiopod groups with the Taghanic Onlap but did not note important evolutionary innovation at that time.

b. In the Lower Tully, but not at its very base (in the Carpenter Falls Bed, Ziegler et al. 1976), and in various other North American regions (e.g., Dawson Bay Formation of Manitoba, Norris \& Uyeno 1971; Bassett Member of the Little Cedar Formation, Iowa, Witzke et al. 1989; Buffalo River Member of the Pine Point Formation, Northwestern Territorries, Lantos 1983), Po. alveoliposticus is a useful index species but it occurs only very rarely outside America and not always at the same level. In the Tafilalt of southern Morocco, we have found one specimen (Pl. 2: 14) in the immediate pre-event interval (shallowing upwards Sellagoniatites Limestone, topmost MD II-C). At Martenberg in the Rhenish Massive, another specimen (Pl. 2: 15) was discovered in the semialternans Zone. The disparillis Zone in the age of most original material from the basal New Albany Shale and lower Antrim Shale of Indiana (Orr \& Klapper 1968). Species such as Po. ovatinodosus and Po. tuberculatus experienced some blooms in the transgressive episode but also range into pre-onlap levels of the Middle varcus Zone (ansatus Zone). Conodonts show no significant extinction at all at the initial Taghanic Event (Aboussalam \& Becker 2000). c. The new data from Morocco (Bou Tchrafine, Ouidane Chebbi) and from the Montagne Noire showed that both Maenioceras and Sellagoniatites, supposed typical middle Givetian index goniatites, may still co-occur with the oldest Pharciceras in equivalents of the $3 \mathrm{rd}$ Tully sequence (MD III-A). Directly associated Maenio. aff. terebratum (Pl. 1: 8-9) and $\mathrm{Ph}$. aff. amplexum (Pl. 1: 12-13) are illustrated from the semialternans Zone (see Pl. 2: 10) of Col de Tribes South, at the eastern slope of the Mont Peyroux of southern France, just $\mathrm{N}$ of section MP-E of Becker (1993). In more basinal sections of the Tafilalt (Hassi Nebech) and in the Dra Valley (Tata region: sections Oufrane, Tiguisselt, Oued Mzerreb), litho- and sequence stratigraphical correlations suggest that a deepening and black shale interval with Afromaenioceras sulcatostriatum, the last Wedekindella brilonensis and Trevoneites (MD II-D) correlates with the $1^{\text {st }} / 2^{\text {nd }}$ Tully sequences. It is conformably overlain by black shales with the oldest Pharciceras (MD III-A).

d. A range of supposed typical middle Givetian trilobite groups survived the pre-Tully regression and initial onlap. The last representative of the Proetinae (Gerastos) was found at Ouidane Chebbi (eastern Tafilalt) in equivalents of the $1^{\text {st }} / 2^{\text {nd }}$ Tully sequence (Bed 2). This has parrallels in a little noticed contemporaneous record of Crassiproetus from the Bassett

Colour-Plate 3. Microfacies of beds around the Taghanic Event Interval at Bou Tchrafine and Pic de Bissous (Scale bars = $1 \mathrm{~mm}$ ). 1. Bou Tchrafine, Bed A3, top of Sellagoniatites Limestone, upper part of ansatus Zone: styliolinid-rich wackestone, followed above a haematite-encrusted small-scale discontinuity surface (ca. 1/3 above base of figure) by styliolinid packstone. The lower styliolinid wackestone contains some thick-shelled, benthic ostracods, crinoid debris, trilobite remains and disarticulated brachiopod shells. In the stylionid packstone the dark micrite was washed out pointing to episodically increased bottom turbulence and condensation. Towards the top of the bed the styliolinid abundancy decreases again. 2. Bou Tchrafine, Bed A4, Styliolinid Bed, top part of ansatus Zone: bioturbated stylionid mudstone-wackestone with some tentaculites (middle left margin), small orthocones, trilobite remains and rare angular quartz grains, followed above an undulating and non-encrusted minor discontinuity surface by styliolinid-richer wackestone. 3. Bou Tchrafine, Bed B1b, Pharciceras aff. amplexum Bed, semialternans Zone: styliolinid wackestone with brachiopods, trilobite remains and rare angular quartz grains, followed above an inconspicuouse undulating discontinuity surface by less fossiliferous, bioturbated styliolinid wackestone/mudstone with rare crinoid debris. Remains of large tabulate/stromatoporoid colonies form unusual shallow-water allochems in the otherwise typical pelagic microfacies. 4. Bou Tchrafine, Bed B2, erraticus Bed, basal (Lower) hermanni Zone: detailed view of bioclastic wackestone with styliolinids, ostracod and brachiopod remains and some pyrite/(secondary) haematite. 5. Pic de Bissous Quarry, Bed 26d2, ansatus Zone: crinoid grainstone/rudstone with some haematite coating and sparite and peloids between partly complete and partly broken ossicles. 6. Pic de Bissous Quarry, Bed 26e5, (-), top ansatus Zone: lower part (A) composed of haematite-rich styliolinid wackestone with ostracods and shell filaments, truncated by an haematite-coated erosional channel (B) which has mostly removed a second wackestone unit (C) which is separated by an undulating stylolitic unconformity surface. The channel is filled by a shallowing upwards wackestone unit (D) with many styliolinids, intraclasts, crinoid debris, ostracods, filaments and trilobite remains. 7. Pic de Bissous Quarry, Bed 26e6, Pharciceras amplexum Bed, semialtemans Zone: haematite-rich, red, bioturbate and nodular wackestone with ostracods, styliolinids and intraclasts in microsparitic matrix. The original internal bedding has been largely destroyed by diagenetic overprinting. 8. Pic de Bissous Quarry, Bed 27a, basal (Lower) hermanni Zone: styliolinid packstone with thin-shelled, pelagic ostracods, haematite and crinoid debris, followed gradually (in the middle part of the section) by less fossiliferous styliolinid wackestone. 
Member of the Little Cedar Formation of Iowa; the genus may range even higher in Iowa (Witke et al. 1989). Homalonotids (Dipleura c'ecayi), Hamilton-type phacopids (Geesops rana), otarionids (Harpidella), asteropygids (Greenops) and Dechenellinae (Monodechenella macrocephala, Pseudodechenella rowi) re-appear in New York in the Upper Tully Limestone (Richter \& Richter 1926, Cooper \& Williams 1935). They are associated with various Hamilton-type brachiopods of the Elytha fimbriata Zone (see Heckel 1973). In the discussion of trilobite extinctions associated with the Taghanic Onlap little attention has been paid so far to the lower Callaway Formation of Missouri which has been correlated with the (post-onlap) lower part of the Cedar Valley Formation of Iowa (e.g., Witzk: et al. 1989, Day 1996b). Faunas listed in Frcunfelter (1967) include brachymetopids (Mystrocephala pulchra), crassiproetines (Crasiproetus calhounensis), Greenops, Phacops, scutelluids, dechenellids (Dechenella aff. norton, Pseudodechenella elevata) and others. A single Aulacopleura (Paraaulacopleura) was mentioned by Basse (1998) from the Tentaculitenschiefer of the northern Rhenish Massive the drowning of most of the massive reefs $a$ the region by this dark shale unit probably has been caused by the Taghanic deepening. On a global scale, there is a remarkable lick of well documented late Givetian trilobite faunas. But it seems clear that only ca. half of all middle Givetian trilobite genera ranged into the event interval.

e. Survival of the initial Taghanic Onlap is also true for some North American brachiopods (Dutro 19:31) rugose and tabulate corals (Heckel 1973) which re-occur in the Bellona and West Brook Beds of the Upper Tully Limestone. In the Tafilalt (Ouidane Chebbi), the cladochonid Bainbridgia alternans was recently discc.vered to range into the level with oldest Pharciceras. It is expected that future work will show the presence of more typical middle Giv stian faunal groups in Tully Limestone equivalents.

\section{Base of Uppel'varcus Zone}

The base of the Upper varcus Zone is traditionally defined by the entry of Po. latifossatus (Ziegler et al 1976) which for phylogenetical and morphokigical reasons (large basal cavity, see Pl. 2: 13) is better placed in Schmidtognathus. Although the species has been recorded almost worldwide (Nevada, Iowa, New York, Morocco, Montagne Noire, Pyrenees, Northern Spain, Sardinia, Austria, Germany, South China: Guangxi, Yunnan, Australia: New South Wales, Queensland), several reasons argue against its use as upper Givetian index conodont:

a. The species enters within the Upper Tully Limestone (within the Moravia Bed of the $3^{\text {rd }}$ sequence) and just postdates the entry of Pharciceras amplexum (Ziegler \& Klapper 1982). A "latifossatus-boundary" would not include the earliest part of the Pharciceras Stufe and would not correlate precisely with significant faunal changes in other groups.

b. In all our investigated sections from Germany (but including none of the three described by Ziegler et al. 1976), the Montagne Noire and from Morocco, Schm. latifossatus is a rather rare species and it was mostly impossible to recognize the Upper varcus Zone in its strict sense. Much easier to place is the entry of its ancestor (see Bultynck \& Hollard 1980), $\mathrm{Oz}$. semialternans. We, therefore, propose to replace the Upper varcus Zone by a semialternans Zone in the standard zonal scheme. Already Bultynck (1987) has introduced a semialternans-latifossatus Zone. Rare oldest Oz. sannemanni (Wirth 1967) and Elsonella rhenana (new record from Ouidane Chebbi) enter at the same time as $O z$. semialternans.

The base of the semialternans Zone correlates with the entry of first Pharciceras (base of international division MD III-A = Pharciceras Genozone) in New York, Morocco, and in the Montagne Noire (new fauna from Col de Tribes South). It coincided with the deepening phase of the $3^{\text {rd }}$ Tully sequence in the type region and with transgressive episodes elsewhere. A range of middle Givetian "holdover taxa" amongst goniatites, corals, brachiopods and trilobites obviously did not overlap with $O z$. semialternans in the Tully Limestone. In the Tata region of southern Morocco, the oldest simple-lobed Pharciceras are associated with first Eobeloceratidae (Mzerrebites juvenocostatus, Bensaid 1974). Regionally typical is also the appearance of Atlantoceras, the first member of the Archoceratidae $\mathrm{n}$. fam. (Gephurocerataceae; also including Archoceras and a related new genus from Ouidane Chebbi) which are defined by only four mature lobes and with very deep, v-shaped ventral and dorsal lobes (true septal folds) as in juvenile Maenio- 
ceratidae, but unlike that found in any Anarcestina or Agoniatitina.

An upper Givetian substage defined by $O z$. semialternans should be considered as a serious option since the species also has an almost worldwide record of first occurrences (Iowa, New York, Morocco, Montagne Noire, Pyrenees, Sardinia, Rhenish Massive, South China, Kolyma of eastern Siberia). A current disadvantage is the unclear ancestry since there are only very few true ozarkodinids in the preceding main Middle varcus (ansatus) Zone. Bultynck (1987) suggested that $O z$. semialternans was derived from $P o$. rhenanus and documented an intermediate specimen with platform remains from an immediate pre-Taghanic level of Morocco (Bou Tchrafine). Consequently, he placed the species in Polygnathus which, however, comprises a number of widely different and not closely related lineages.

\section{Base of (Lower) hermanni Zone}

The base of the zone is defined by the entry of Schm. hermanni or of alternative index conodonts such as Schm. wittekindti, Schm. pietzneri and Po. limitaris. Po. dubius and Po. ordinatus also enter within the zone. Using its base for the definition of an upper Givetian would have some advantages:

a. As just outlined, the base of the hermanni Zone is marked by a significant post-Taghanic conodont radiation and can be easily recognized by a number of index species belonging to different phylogenetic lineages.

b. The boundary between the varcus and hermanni Zones is also characterized by a smallscale global conodont extinction (Aboussalam \& Becker 2000) which terminated, for example, Po. linguiformis mucronatus (compare Pl. 2: 11-12), Po. linguiformis klapperi, Po. linguiformis transversus, the last Po. parawebbi, and, perhaps, the last Bipennatus. In many sections, Po. linguiformis linguiformis became rare with the end of the varcus (semialternans) Zone.

c. The conodont extinction event coincided with the final extinction of Maenioceratidae and of the last Agoniatitidae; both were always regarded as typical middle Givetian groups. Similar Taghanic Onlap survivor extinctions may apply to some corals and brachiopods. Only ca. half of the known trilobite genera (Phacops, Cyphaspis, Longicoryphe, Richteras- pis, Scutellum, Harpes, Greenops, Bradocryphaeus, Heliopyge, Neometacanthus, "Gondwanapis") survived into the post-event late Givetian.

$\mathrm{d}$. The base of the hermanni Zone correlates with the entry of easily recognizable goniatites such as Mzerrebites erraticus (in North Africa and in the Rhenish Massive) and of advanced (involute or multilobate) pharciceratids (MD III-B). Surprisingly, this significant gradual upper Givetian radiation is not known to have been parallelled in the trilobite evolution.

e. The base of the hermanni Zone coincided with a significant eustatic transgression. In New York this is well marked by the base of the Geneseo blackshale (House 1983) which sits on a post-Tully erosional unconformity (Brett \& Baird 1996), partly marked by the oldest Leicester Pyrite (Huddle 1981). In Iowa the global sealevel rise was recognized as base of a middle subdivision of the eustatic Depophase IIa (IIa-2, Witzke et al. 1989), or as regional T-R cycle 3B (Day 1996b).

Disadvantages of a hermanni-defined substage would be as follows:

a. The basal part (first zone, MD III-A) of the Pharciceras Stufe as defined by House (1985) would be excluded from the upper Givetian.

b. The base of the substage would lie $1 \frac{1 / 2}{2}$ conodont zones and up to two ammonoid zones (Fig. 1) higher than the initial Taghanic Onlap.

\section{Conclusions}

Two different conodont-goniatite levels are available which might be used to define an upper Givetian substage: the base of the $O z$. semialternans Zone $=$ base of Pharciceras Genozone (MD III-A), or the base of the Schm. hermanni Zone $=$ base of Stenopharciceras Genozone (MD III-B, regional Mzerrebites erraticus Zone of SE Morocco, House \& Becker 1999). Both levels correlate with eustatic transgressions subsequent to the initial and main Taghanic Onlap and can be recognized nearly worldwide, at least in pelagic facies.

\section{Acknowledgements}

This study was conducted within the frame of the DFG-financed Graduiertenkolleg on "Evolutionary Transformations and Mass Extinctions" at the Museum für Naturkunde, Berlin. We appreciate the field company in Morocco by our 
friends Dr. V. Ebtighausen (Odenthal). J. Bockwinkel (L.everkusen). Prof. $f_{i}$. El Hassani (Rabat) and Prof, M. R. House (Southampton): the latter and Dr. D. Weyer (Berlin) also provided helpful comments on the manuscript. We like to express our thanks to Dr. M. Dahmani and others from the Ministére de IIndustrie. du Commerce, de l'Énergie ct des Mines who en:ble research in Morocco. Aspects of conodont taxonomy were discussed with our friends Prof. G. Klapper (Iowa City), Prof. W. T. Kirchgasser (Potsdam, New York) and I'rof. P. Bultunck (Bruxelles). Ammonoid specimens were prepared by Mrs. E. Stenzel. many conodont samples were proc sssed by Mrs. S. Salzmann. Mrs. W. Harre conducted photographic work. Dr. A. Greshake helped to photo thin section, and Dr. E. Wäsch and P. Czaja assisted in the SEM laboratory. Dr. R. Feist led us to the Col de Tribes South secticn in the Montagne Noire.

\section{References}

Aboussalam. Z. S. 2000. Das Taghanic-Event im oberen Mitteldevon von I iuropa und Nord-Afrika. - Terra Nostra 00/3: 1

Aboussalam. Z. S. \& Becker. R. T. 2000. Conodont diversity around the Tashanic Event. - Document International Subcommission on Devonian Stratigraphy, Rio de Janeiro, August 2000: $12 \mathrm{pp}$.

Basse. M. 1998. Tiilobiten aus mittlerem Devon des Rhenohercynikums: III. Proetida (3). Phacopida (2). Lichida (Lichoidea, Odontopleuroidea) und ergänzende Daten. Palaeontograptica $249(1-6): 1-162$.

Becker, R. T. 1913. Stratigraphische Gliederung und Ammonoideen-Fat nen im Nehdenium (Oberdevon II) von Europa und Nord-Afrika. - Courier Forschungs-Institut Senckenberg 1:55, $405 \mathrm{pp}$.

Becker, R. T. \& House, M. R. 1994. International Devonian goniatite zonation, Emsian to Givetian, with new records from Morocco - Courier Forschungs-Institut Senckenberg 169: $79-135$.

- 1999. Late Givetian and Frasnian ammonoid succession at Bou Tchrafine (Anti-Atlas. Southern Morocco). In A. El Hassani and $\lambda$. Tahiri (eds). SDS-IGCP 421 Meeting. April $24^{\text {th }}$ - May 1 $1^{\text {st }}$, Excursion Guidebook, Part I, Tafilalt and Maider (eastern Anti-Atlas): 21-27: Rabat [also published as Noles Mémoires du Service Géologique Maroc 399: $27-36$.

- 2000. Devonial ammonoid zones and their correlation with established series and stage boundaries. - Courier Forschungs-Ins:itut Senckenberg 220: 113-151.

Bensaid. M. 1974 Etude sur des Goniatites a la limite du Devonien Moyen et Supérieur, du Sud Marocain. - Notes de Service de la Carte géologique Maroc 36: 81-140.

Bensaid. M. Bultunck. P.. Sartenaer. P.. Walliser. O. H. \& Ziegler, W. 198.5. The Givetian-Frasnian boundary in preSahara Morocro. - Courier Forschungs-Institut Senckenberg 75: $287 \ldots 00$

Bischoff. G. \& Zit gler. W. 1957. Die Conodontenchronologie des Mitteddevons und des tiefsten Oberdevons. - Abhandlungen dis hessischen Landesamtes für Bodenforschungen 22: $136 \mathrm{pp}$.

Brett. C. E. \& Ba:rd. G. C. 1996. Devonian sedimentary cycles and sequer ces in the northern Appalachian Basin. Geological Suciety of America. Special Paper 306 $213-241$.

Brett. C. E., Bairt. G. \& Ver Straeten. C. A. 1999. Flexural events and faunal changes preceding the third Acadian Tectophase in the late Givetian of the Northern Appalachian Basin region. - Errachidia Meeting SDS - IGCP 421. April 23 - May $1^{\text {st }}$. Abstract Book: 4-5.

Brice. D. Bultync \&, P. Colbeaux. J. P., Lethiers, F. Mistiaen. B. Rohart. J. C. \& Bigey, F. 1976. Une nouvelle coupe dans le Dévonien de Ferques (Boulonnais, France). Annales de Societé Géologique du Nord 96 (2): 135-155.

Bultynck. P. 1987. Pelagic and neritic conodont successions from the Givetian of pre-Sahara Morocco and the Ardennes. - Bulletin de l'Institut royal des Sciences naturelles de Belgique 57: 149-181.

Bultynck. P. \& Hollard, H. 1980. Distribution comparée de Conodontes et Goniatites dévoniens des plaines du Dra du Máder et du Tafilalt (Maroc). - Aardkundige Mededelingen 1: 7-73.

Bultynck, P. \& Jacobs, L. 1981. Conodontes et sédimentologie des couches de passage du Givetian au Frasnien dans le nord du Tafilalt et dans le Máder (Maroc présaharien). - Bulletin de l'Institut royal des Sciences naturelles de Belgique 56: 269-280.

Bultynck. P.. Casier, J.-G., Coen-Aubert, M. \& Godefroid, J. 2001. Pre-conference field trip (V1): Couvin-PhillipevilleWellin area. Ardenne (May 11-12, 2001). - 15 $5^{\text {th }}$ International Senckenberg Conf., Joint Meet. IGCP 421/SDS, May 200I. Field trips guidebook: 1-44.

Chlupac, I. Feist. R. \& Morzadec, P. 2000. Trilobites and standard Devonian stage boundaries. - Courier Forschungs-Institut Senckenberg 220: 87-98.

Conkin. J. E. \& Conkin. B. M. 1970. Middle Devonian arenaceous foraminifera of central Ohio. Part 1 - Revision of the genus Webbinelloidea Stewart and Lampe, 1947. Micropalaeontology 16 (1): 1-14.

Cooper. G. A. 1967. Age and correlation of the Tully and Cedar Valley Formations in the United States. In D. H. Oswald (ed.). International Symposium on the Devonian System. Calgary 1967 II: $701-709$.

Cooper. G. A. \& Williams, J. S. 1935. Tully Formation of New York. - Geological Society of North America, Bulletin 46: 781-868.

Day, J. 1996a. Middle-Upper Devonian relative sea-level history of central and western North American interior basins. - Geological Society of America, Special Paper 306: $259-275$

- 1996b. Faunal signatures of Middle-Upper Devonian depositional sequences and sea level fluctuations in the Iowa Basin: U.S. Midcontinent. - Geological Society of America, Special Paper 306: 277--300.

Dutro. J. T. jr. 1981. Devonian brachiopod biostratigraphy of New York State. In Oliver, W. A. jr. \& Klapper, G. (eds). Devonian biostratigraphy of New York, Part I., International Subcommission on Devonian Stratigraphy: 67-82.

Ebert. J. 1993. Globale Events im Grenz-Bereich MittelOber-Devon. - Göttinger Arbeiten zur Geologie und Paläontologie 59. $106 \mathrm{pp}$.

Feist. R. 1991. The Late Devonian trilobite crises. - Historical Biology 5: 197-214.

Feist. R. \& Klapper. G. 1985. Stratigraphy and conodonts in pelagic sequences across the Middle-Upper Devonian boundary, Montagne Noire, France. - Palaeontographica, Abt. A 188 (1-3): 1-18.

Fraunfelter. G. H. 1967. Middle Devonian Biofacies of central and northeastern Missouri. In D. H. Oswald (ed.) International Symposium on the Devonian System, Calgary 1967 II: $693-700$.

Heckel. P. H. 1973. Nature, origin, and significance of the Tully Limestone. - Geological Society of America. Special Paper 138: 244 pp.

House. M. R. 1962. Observations on the ammonoid succession of the North American Devonian. - Journal of Paleontology 36 (2): $247-284$.

- 1975. Faunas and time in the marine Devonian. - Proceedings of the Yorkshire Geological Society $\mathbf{4 0}$ (4): $459-493$.

- 1982. The Middle/Upper Devonian series boundary and decisions of the International Geological Congress. Courier Forschungs-Institut Senckenberg 55: 449-462.

-1983. Devonian eustatic events. - Proceeding of the Ussher Society 5: 396-405. 
- 1985. Correlation of mid-Palaeozoic ammonoid evolutionary events with global sedimentary perturbations. - Nature 313: $17-22$.

- 1995. Devonian precessional and other signatures for establishing a Givetian timescale. - Geological Society of America, Special Publication 85: 37-49.

- 1989. Ammonoid extinction events. - Philosophical Transactions of the Royal Society of London B325: 307-326.

House, M. R. \& Becker, R. T. 1999. Goniatite biozonation of the Pharciceras Stufe (late Givetian - basal Frasnian). Errachidia Meeting SDS - IGCP 421, April 23 $3^{\text {rd }}-$ May $1^{\text {st }}$, Abstract Book: 22-23.

Huddle, J. W. 1981. Conodonts from the Genesee Formation in western New York. - United States Geological Survey, Professional Paper 1032B: 66 pp.

Kirchgasser, W. T. 1970. Conodonts from near the Middle/ Upper Devonian boundary in North Cornwall. - Palaeontology 13: $335-354$.

Klapper, G. 1989. The Montagne Noire Frasnian (Upper Devonian) conodont succession. - Canadian Society of Petroleum Geology, Memoirs 14 (III): 449-468.

Klapper, G., Feist, R. \& House, M. R. 1987. Decision on the Boundary Stratotype for the Middle/Upper Devonian Series Boundary. - Episodes 10 (2): 97-101.

Johnson, J. G. 1970. Taghanic onlap and the end of North American provinciality. - Geological Society of America, Bulletin 81: 2077-2106.

Johnson, J. G., Klapper, G. \& Sandberg, C. A. 1985. Devonian eustatic fluctuations in Euramerica. - Geological Society of America, Bulletin 96: 567-587.

Johnson, J. G., Sandberg, C. A. \& Poole, F. G. 1989. Early and Middle Devonian paleogeography of Western United States. - Canadian Society of Petroleum Geologists, Memoirs 14 (I): 161-182.

Lantos, J. A. 1983. Middle Devonian stratigraphy north of the Pine Point barrier complex, Pine Point, Northwest Territorries. - M.Sc. thesis, University of Alberta, $195 \mathrm{pp}$.

Lottmann, J. 1990. Die pumilio-Events. - Göttinger Arbeiten zur Geologie und Paläontologie 44: $98 \mathrm{pp}$.

Norris, A. W. \& Uyeno, T. T. 1971. Stratigraphy and Conodont faunas of Devonian outcrop belts. - Geological Association of Canada, Special Paper 9: 209-223.
Oliver, W. A. \& Pedder, A. E. H. 1994. Crisis in the Devonian history of the rugose corals. - Paleobiology 20 (2): $178-190$.

Orr, W. 1964. Conodonts from the Devonian Lingle and Alto Formations of saouthern Illinois. - Illinois State Geological Survey, Circular 361: 28 pp.

Orr, W. \& Klapper, G. 1968. Two new conodont species from the Middle-Upper Devonian boundary beds of Indiana and New York. - Journal of Paleontology 42: $1066-1076$.

Richter, R. \& Richter, E. 1926. Die Trilobites des Oberdevon. - Abhandlungen der preußischen geologischen Landesanstalt, Neue Folge 99: 314 pp. + 12 pls.

Struve, W. 1992. Neues zur Stratigraphie und Fauna des rhenotypen Mittel-Devon. - Senckenbergiana lethaea $71(5 / 6)$ : 503-62.

Walliser, O. H. 1990. Marble Quarry at Pic de Bissous. Document of the Subcommission on Devonian Stratigraphy (ICS, IUGS), Frankfurt/M., Sept. 1990: 2 pp.

Wedekind, R. 1913. Die Goniatitenkalke des unteren Oberdevon von Martenberg bei Adorf. - Sitzungsberichte der Gesellschaft naturforschender Freunde, Berlin 1913 (1): 23-85.

Wirth, M. 1967. Zur Gliederung des höheren Paläozoikums (Givet-Namur) im Gebiet des Quinto Real (Westpyrenäen) mit Hilfe von Conodonten. - Neues Jahrbuch für Geologie und Paläontologie, Abhandlungen 127 (2): 179-244.

Witzke, B. J., Bunker, B. J. \& Rogers, F. S. 1989. Eifelian through lower Frasnian stratigraphy and deposition in the Iowa area, Central Midcontinent, U.S.A. - Canadian Society of Petroleum Geologists, Memoir 14 (I): 221-250.

Ziegler, W. \& Klapper, G. 1982. The disparilis conodont zone, the proposed level for the Middle-Upper Devonian boundary. - Courier Forschungs-Institut Senckenberg 55: 463-492.

Ziegler, W., Klapper, G. \& Johnson, J. G. 1976. Redefinition and subdivision of the varcus-Zone (Conodonts. Middle?Upper Devonian) in Europe and North America. Geologica et Palaeontologica 10: 109-140. 